\title{
Expression of protease nexin- 1 and plasminogen activators during follicular growth and the periovulatory period in cattle
}

\author{
Mingju Cao, José Buratini Jr ${ }^{1}$, Jacques G Lussier, Paul D Carrière and Christopher A Price \\ Centre de Recherche en Reproduction Animale (CRRA), Faculté de Médecine Vétérinaire, Université de Montréal, \\ C.P. 5000 St-Hyacinthe, Québec, Canada and ${ }^{1}$ Departamento de Fisiologialnstituto de Biociências, Universidade \\ Estadual Paulista, Botucatu, São Paulo, Brazil
}

Correspondence should be addressed to C A Price; Email christopher.price@umontreal.ca

M Cao is currently at the Division of Experimental Medicine, McGill University, Royal Victoria Hospital, Montreal,

Quebec, Canada

\begin{abstract}
Extracellular matrix remodeling occurs during ovarian follicular development, mediated by plasminogen activators (PAs) and PA inhibitors including protease nexin-1 (PN-1). In the present study we measured expression/activity of the PA system in bovine follicles at different stages of development by timed collection of ovaries during the first follicular wave and during the periovulatory period, and in follicles collected from an abattoir. The abundance of mRNA encoding PN-1, tissue-type PA (tPA), urokinase (uPA) and PA inhibitor-1 (PAI-1) were initially upregulated by human chorionic gonadotropin (hCG) in bovine preovulatory follicular wall homogenates. PN-1, PAI-1 and tPA mRNA expression then decreased near the expected time of ovulation, whereas uPA mRNA levels remained high. PN-1 concentration in follicular fluid (FF) decreased and reached the lowest level at the time of ovulation, whereas plasmin activity in FF increased significantly after hCG. Follicles collected from the abattoir were classified as non-atretic, early-atretic or atretic based on FF estradiol and progesterone content: PN-1 protein levels in FF were significantly higher in non-atretic than in atretic follicles, and plasmin activity was correspondingly higher in the atretic follicles. No changes in PN-1 levels in FF were observed during the growth of pre-deviation follicles early in a follicular wave. These results indicate that PN-1 may be involved in the process of atresia in non-ovulatory dominant follicles and the prevention of precocious proteolysis in periovulatory follicles.

Reproduction (2006) 131 125-137
\end{abstract}

\section{Introduction}

The growth of bovine follicles from the primordial to the preovulatory stage is characterized by the proliferation of cells and considerable increase in size of the follicle (Lussier et al. 1987). The granulosa and theca cell layers are separated by the basal lamina, and the theca cells are enclosed in a dense extracellular matrix (ECM). Remodeling of the basal lamina and ECM occurs as follicles expand, and changes in the chemical composition of the basal lamina have been described during follicular development (Rodgers et al. 2003). Extensive breakdown and remodeling of the basal lamina and connective tissue of the follicular wall is required for ovulation (Curry et al. 2001, Richards et al. 2002).

The plasminogen activator (PA) system has been implicated as one of the important mediators of ECM remodeling and follicular rupture at ovulation (Ny et al. 2002, Liu 2004). The PA system consists of the ubiquitous proenzyme, plasminogen, that is converted to an active enzyme, plasmin, by the tissue-type (tPA) and urokinase
(uPA) PAs. The activity of PA is regulated in part by inhibitors, including PA inhibitor-1 (PAI-1) and protease nexin-1 ( $\mathrm{PN}-1$, also known as serine protease inhibitor E2). PN-1 is a secreted glycoprotein, and is a broad and rapid inhibitor of a number of serine and cysteine proteases including tPA, uPA and plasmin (Silverman et al. 2001). The expression and regulation of $\mathrm{PN}-1$ has been examined in ovarian follicles. In contrast to PAI-1, which is predominantly expressed in thecal-interstitial cell layers, $\mathrm{PN}-1$ was exclusively expressed in granulosa cells in mice (Hägglund et al. 1996), rats (Hasan et al. 2002) and cattle (Bédard et al. 2003).

Previous studies indicate that ovulation requires coordinated expression of the PAs and their inhibitors. In rats and monkeys, there is an upregulation of tPA and PAI-1 expression by human chorionic gonadotropin (hCG) during the periovulatory period, followed by a marked decrease in PAI-1 expression just before ovulation. This may allow a narrow window of increased tPA activity that results in follicular rupture and ovulation (Liu et al. 1987, 
Shen et al. 1997, Liu 2004). PN-1 is also expressed in preovulatory follicles, although its role is not clear. PN-1 expression decreased following an ovulatory dose of hCG in rats (Hasan et al. 2002) but not in mice (Hägglund et al. 1996). How the proteolytic cascade is controlled in cattle is not well understood, as tPA activity increases prior to ovulation, whereas PAI-1 activity does not change (Dow et al. 2002a, 2002b). The potential role of PN-1 during the periovulatory period in cattle remains to be determined.

The PA system may also be involved in tissue remodeling at earlier stages of folliculogenesis. In rats, there is a switch from uPA to PPA activity during follicular growth (Karakji \& Tsang 1995). In cattle, follicular growth occurs in waves, during which the dominant, potential ovulatory follicle undergoes rapid growth and the subordinate follicles become atretic (Fortune et al. 2001, Ginther et al. 2001b). The PA system may be involved in the growth of the dominant follicle, as cellular uPA activity was higher in granulosa cells from small antral follicles compared with those from large follicles, and PN-1 secretion and expression was lower in granulosa cells from small follicles compared with those of large follicles of rodents and cattle (Hägglund et al. 1996, Bédard et al. 2003, Cao et al. 2004). Follicular regression may also involve PA activity, as plasminogen activation markedly decreased attachment of Chinese hamster ovary fibroblasts to ECM components in vitro, resulting in detachment-induced cell death (anoikis) (Rossignol et al. 2004). Interestingly, PN-1 inhibited PAinduced anoikis in these cells (Rossignol et al. 2004).

The objective of this study was to determine if cellspecific and temporal regulation of $\mathrm{PN}-1$ and $\mathrm{PA}$ expression and secretion contribute to follicular development and ovulation in cattle. We assessed the role of $\mathrm{PN}-1$ as a candidate for regulation of PA activity in bovine follicles at three stages of folliculogenesis: (i) the periovulatory period; (ii) in healthy, early-atretic and atretic dominant follicles classified on biochemical criteria; and (iii) during the first follicular wave before and during follicular deviation.

\section{Materials and Methods}

Experiments 1 and 3 were performed with cross-bred heifers aged between 1.5 and 3 years. The animals were housed indoors on the University of Montreal farm for the duration of the experiment and were fed concentrate and hay twice daily. Water was freely available. All animal experimentation was approved by the Animal Care Committee of the Faculty of Veterinary Medicine, University of Montreal, and performed in accordance with Canadian Council of Animal Care Guidelines.

\section{Experiment 1: hCG-induced periovulatory follicles}

\section{Experimental design}

Ten heifers were induced to ovulate as described (Bédard et al. 2003). Animals with a corpus luteum were synchronized with one injection of prostaglandin $\mathrm{F} 2 \alpha$ (PGF2 $\alpha$ ) (25 mg, i.m.) (Lutalyse; Upjohn, Kalamazoo, MI, USA), and behavioral estrus was monitored at $12 \mathrm{~h}$ intervals, from 48 to $96 \mathrm{~h}$ following PGF2 $\alpha$ injection. Ovarian follicular development was monitored by daily transrectal ultrasonography performed with a real-time linear scanning ultrasound system (LS-300; Tokyo Keiki Co., Ltd, Tokyo, Japan) equipped with a $7.5 \mathrm{MHz}$ transducer (Lussier et al. 1994). Preovulatory follicles were obtained following a second injection of $25 \mathrm{mg}$ PGF2 $\alpha 7$ days after estrus to induce luteolysis, thereby allowing the development of the dominant follicle of the first follicular wave into a preovulatory follicle (Sirois 1994). An ovulatory dose of hCG (3000 IU) (APL; Ayerst Lab., Montreal, QC, Canada) was injected $36 \mathrm{~h}$ after the induction of luteolysis, and ovaries bearing the preovulatory follicle were collected by ovariectomy at $0,6,12,18$ and $24 \mathrm{~h}$ after hCG injection.

Follicular fluid (FF) was aspirated from the follicles with a $21 \mathrm{G}$ needle, centrifuged ( $3000 \mathrm{~g}$ for $2 \mathrm{~min}$ at $4^{\circ} \mathrm{C}$ ) and stored at $-20^{\circ} \mathrm{C}$ for PN-1 and PA assay. The follicle walls were then homogenized in lysis buffer ( $4 \mathrm{M}$ guanidium isothiocyanate, $0.5 \%$ sodium $\mathrm{N}$-laurylsarcosine, $25 \mathrm{mM}$ sodium citrate, pH 7) (Chomczynski \& Sacchi 1987), and total RNA was sedimented on a cesium chloride cushion by centrifugation (Ndiaye et al. 2005). The concentration of total RNA was evaluated by optical density at $260 \mathrm{~nm}$, and quality was estimated by visualizing the $28 \mathrm{~S}$ and $18 \mathrm{~S}$ ribosomal bands following electrophoretic separation on a formaldehyde-agarose gel in the presence of ethidium bromide.

Granulosa cells were collected from individual follicles at 0,12 and $24 \mathrm{~h}$ following hCG injection for protein extraction. Cells were homogenized in M-PER Reagent (Pierce, Rockford, IL, USA) supplemented with Complete Protease Inhibitor Cocktail (Roche Applied Science, Laval, QC, Canada). Lysis of cells was achieved by repeated passage through a $25 \mathrm{G}$ needle attached to a $3 \mathrm{ml}$ syringe. Cell lysates were centrifuged ( $16000 \mathrm{~g}$ for $15 \mathrm{~min}$ at $4^{\circ} \mathrm{C}$ ) and supernatant was stored at $-80^{\circ} \mathrm{C}$ until analysis of $\mathrm{PN}-1$ and PA activity.

\section{$m R N A$ reverse transcriptase and semi-quantitative} $R T-P C R$

One microgram of total RNA was reverse transcribed and amplified for 15 cycles with the SMART PCR cDNA synthesis kit (BD Biosciences Clontech, Mississauga, ON, Canada) as described (Ndiaye et al. 2005). The resulting cDNA pool was diluted to $50 \mu \mathrm{l}$ in TE buffer $(10 \mathrm{mM}$ Tris $\mathrm{pH} 8,1 \mathrm{mM}$ EDTA), and $1 \mu \mathrm{l}$ of the aliquot was used in a secondary $100 \mu \mathrm{l}$ PCR reaction for 18 cycles using the Advantage 2 DNA Polymerase Mix (BD Biosciences Clontech) and the PCR primer AAGCAGTGGTAACAACGCAGAGT.

CDNA from the secondary PCR reactions were diluted 10-fold in TE buffer, and used as a template in subsequent 
semi-quantitative RT-PCR for the target genes PN-1, PAI-1, tPA and uPA. Table 1 summarizes the gene-specific PCR primers used and PCR conditions. GAPDH was used as the housekeeping control (Ndiaye et al. 2005). Briefly, an aliquot of $2 \mu \mathrm{l}$ of the diluted cDNA was amplified using Advantage 2 DNA polymerase $(0.6 \mu \mathrm{l})$ in a $25-\mu \mathrm{l}$ PCR reaction containing $0.4 \mathrm{mM} \mathrm{dNTP}$ mix, and $0.8 \mu \mathrm{M}$ specific primers (except for GAPDH, $0.4 \mu \mathrm{M}$ ). Target CDNA was amplified in a PCR thermal cycler (Gene AMP PCR System 9700; Applied Biosystems, Foster City, CA, USA) under the following conditions: (i) an initial denaturation step for $1 \mathrm{~min}$ at $95^{\circ} \mathrm{C}$; and (ii) amplification cycles with denaturation at $95^{\circ} \mathrm{C}$ for $30 \mathrm{~s}$, annealing for $45 \mathrm{~s}$ at the temperatures indicated in Table 1 for each gene, and elongation at $68^{\circ} \mathrm{C}$ for $1.5 \mathrm{~min}$. The number of PCR cycles was optimized for each gene to be analyzed (see Table 1). The amplicons were separated on $1 \%$ agarose gel containing ethidium bromide, and visualized under UV light. Quantification of band intensity was performed with NIH Image software. Target gene mRNA abundance was normalized to GAPDH mRNA abundance.

\section{Experiment 2: healthy and atretic large follicles}

\section{Tissue collection}

Ovaries were obtained from an abattoir local to the São Paulo State University campus in Botucatu, and transported to the laboratory in saline on ice. Follicles were dissected from the ovaries and measured with calipers. Ovaries with a follicle $\geq 9 \mathrm{~mm}$ in diameter (and therefore post-deviation, dominant follicles) were selected, and FF from that follicle was aspirated, centrifuged and frozen for steroid, PN-1 and PA assay. The antral cavity was flushed repeatedly with cold saline and granulosa cells recovered by centrifugation at $1200 \mathrm{~g}$ for $1 \mathrm{~min}$, and pooled with the
FF cell pellet. The remaining granulosa cells adhering to the follicle wall were removed by gently scraping with a blunt Pasteur pipette, and pooled with the flushed cells. The theca layer was then removed with forceps and washed in saline by passing repeatedly through a $1 \mathrm{ml}$ syringe. Granulosa and theca cell were collected into Trizol (Invitrogen; São Paulo, Brazil) and homogenized with a Polytron. Total RNA was extracted immediately according to the Trizol protocol.

Follicles containing $>100 \mathrm{ng}$ estradiol $/ \mathrm{ml}$ and $<100 \mathrm{ng}$ progesterone/ml were classified as non-atretic $(n=7)$, those containing $<40 \mathrm{ng}$ estradiol/ml and $<100 \mathrm{ng}$ progesterone/ml were classified as early atretic $(n=7)$, and those containing $<40 \mathrm{ng}$ estradiol/ml and $>100 \mathrm{ng}$ progesterone $/ \mathrm{ml}$ were classified as atretic $(n=4)$. These represent mature dominant growing, static and regressing follicles respectively (Price et al. 1995). Cross-contamination of theca and granulosa cells was tested by detection of mRNA encoding cytochromes P450 aromatase (Cyp19) and $17 \alpha$-hydroxylase (Cyp17) in each sample by PCR (Buratini et al. 2005). Only granulosa cell samples negative for Cyp17, and only thecal samples negative for Cyp19 amplicons were included in the analysis (number of follicles used given above).

\section{Semi-quantitative RT-PCR}

$\mathrm{PN}-1, \mathrm{PPA}$ and $\mathrm{uPA}$ mRNA expression in granulosa cells, and PAI-1, tPA and uPA mRNA expression in theca cells were measured by semi-quantitative RT-PCR. Briefly, for both theca and granulosa cells, total RNA $(1 \mu \mathrm{g})$ was incubated with DNAse I (Invitrogen) and reverse transcribed with SuperScript II (Invitrogen) and oligo-d(T) primer (Buratini et al. 2005). An aliquot $(0.4 \mu \mathrm{l})$ of the cDNA template was amplified by PCR using $0.2 \mu \mathrm{l}(2.5 \mathrm{U})$ Taq Polymerase (Amersham Pharmacia Biotech, Inc., Oakville, ON, Canada) in a $20 \mu \mathrm{l} \mathrm{PCR}$ buffer (Amersham Pharmacia

Table 1 Summary of RT-PCR protocols in Experiments 1 and 2.

\begin{tabular}{|c|c|c|c|c|c|c|c|c|}
\hline \multirow[b]{2}{*}{ Gene } & & \multirow[b]{2}{*}{ Primers } & \multirow[b]{2}{*}{ Size (bp) } & \multicolumn{2}{|c|}{$\begin{array}{c}\text { Annealing } \\
\text { temperature }\left({ }^{\circ} \mathrm{C}\right)\end{array}$} & \multicolumn{2}{|c|}{ Cycles } & \multirow[b]{2}{*}{ Reference } \\
\hline & & & & Expt 1 & Expt 2 & Expt 1 & Expt 2 & \\
\hline $\mathrm{PN}-1$ & $\begin{array}{l}\text { S: } \\
\text { AS: }\end{array}$ & $\begin{array}{l}\text { 5'-TCCGTGACGTTGCССТСТGTG-3' } \\
5^{\prime} \text {-CCGTGATCTCCACAAАCССТT-3' }\end{array}$ & 555 & 64 & 62 & 17 & 24 & Bédard et al. (2003) \\
\hline PAI-1 & $\begin{array}{l}\text { S: } \\
\text { AS: }\end{array}$ & $\begin{array}{l}\text { 5'-GAACAAGGATGAGATCAGCACAGC-3' } \\
5^{\prime} \text {-GACACGTACAGAAACTCTTGATCTG-3' }\end{array}$ & 696 & 64 & 62 & 22 & 30 & NM_174137 \\
\hline tPA & $\begin{array}{l}\text { S: } \\
\text { AS: }\end{array}$ & 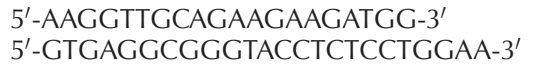 & 479 & 56 & 55 & 20 & 26 & Macchione et al. (2000) \\
\hline uPA & $\begin{array}{l}\text { S: } \\
\text { AS: }\end{array}$ & $\begin{array}{l}\text { 5'-GTCTGGTGAATCGAACTGTGGC-3' } \\
\text { 5'-GGCTGCAAACCAAGGCTG-3' }^{\prime}\end{array}$ & 511 & 58 & 65 & 25 & 30 & Balcerzak et al. (2001) \\
\hline GAPDH & $\begin{array}{l}\text { S: } \\
\text { AS: }\end{array}$ & $\begin{array}{l}5^{\prime} \text {-TGTTCCAGTATGATTCCACCCACG-3' } \\
5^{\prime} \text {-CTGTTGAAGTCGCAGGAGACAACC-3' }\end{array}$ & 600 & 64 & - & 21 & - & Fayad et al. (2004) \\
\hline $\mathrm{H} 2 \mathrm{a}$ & $\begin{array}{l}\text { S: } \\
\text { AS: }\end{array}$ & $\begin{array}{l}5^{\prime} \text {-GTCGTGGCAAGCAAGGAG-3' } \\
5^{\prime} \text {-GATCTCGGCCGTTAGGTACTC-3' }\end{array}$ & 182 & - & 55 & - & 30 & Robert et al. (2002) \\
\hline GAPDH & $\begin{array}{l}\text { S } \\
\text { AS: }\end{array}$ & $\begin{array}{l}\text { 5'-TGTTCCAGTATGATTCCACC-3' } \\
\text { 5'-TCCACCACCCTGTTGCTG-3' }^{\prime}\end{array}$ & 860 & - & 55 & - & 26 & Tsai et al. (1996) \\
\hline
\end{tabular}


Biotech) containing $0.1 \mathrm{mM}$ dNTP mix, and $0.2 \mu \mathrm{M}$ specific primers (Cao et al. 2004). Target cDNA was amplified under the following conditions: (i) an initial denaturation step for $3 \mathrm{~min}$ at $94^{\circ} \mathrm{C}$, except uPA, which was for 5 min at $95^{\circ} \mathrm{C}$; (ii) amplification cycles with denaturation at $94^{\circ} \mathrm{C}$ for $15 \mathrm{~s}(\mathrm{PN}-1), 30 \mathrm{~s}$ (uPA, tPA, PAI-1 and GAPDH) or $45 \mathrm{~s}$ for histone $\mathrm{H} 2 \mathrm{a}(\mathrm{H} 2 \mathrm{a})$, annealing for $30 \mathrm{~s}$ for $\mathrm{H} 2 \mathrm{a}$ and $45 \mathrm{~s}$ for all other genes, at the temperatures indicated in Table 1, and elongation at $72{ }^{\circ} \mathrm{C}$ for $1 \mathrm{~min}$; and (iii) final elongation at $72^{\circ} \mathrm{C}$ for $5 \mathrm{~min}$. The number of cycles is given in Table 1.

Semi-quantitative RT-PCR was validated for each gene product (Cao et al. 2004). The PCR products $(10 \mu \mathrm{l})$ were separated on $1 \%$ agarose gels containing ethidium bromide, and visualized under UV light. Quantification of band intensity was performed with NIH Image software. Target gene mRNA abundance was expressed relative to H2a mRNA abundance in granulosa cells, and to GAPDH mRNA abundance in theca cells.

\section{Experiment 3: early in the follicular wave}

Seven heifers were first synchronized with two injections of PGF $2 \alpha$ given 11 days apart. Ovulation and follicular development was monitored daily or twice daily by transvaginal ultrasonography, and follicles were punctured as described (Ouellette et al. 2005) when the largest follicle of the first wave had reached $6.5,7.5,8.5$ or $9.5 \mathrm{~mm}$ internal diameter (referred to as 'follicular stage'), corresponding to approximately $1,1.5,2$ and 2.5 days after wave emergence (Ginther et al. 2001b). Follicular deviation is expected to occur when the largest follicle reaches $8.5-9 \mathrm{~mm}$ diameter (Beg et al. 2001). FF from the largest three follicles (F1, F2 and F3) was collected separately for each follicle ('follicular rank'). Each animal was used once during a follicular wave, and 5-6 days after follicular puncture each animal received a single injection of PGF2 $\alpha$ to initiate ovulation and a new first follicular wave. Each animal was in this manner sampled on four consecutive estrous cycles. Only clear FF samples without blood contamination were used. The FF was centrifuged for $15 \mathrm{~min}$ at $2000 \mathrm{~g}$ and the supernatant frozen at $-20^{\circ} \mathrm{C}$ until assayed for steroid concentrations, $\mathrm{PN}-1$ content and PA activity.

\section{Casein zymography}

Casein zymography was used to measure plasmin, tPA and UPA activity in FF and cell extracts as described (Cao et al. 2004). Briefly, $2 \mu \mathrm{FF}$ or $30 \mu \mathrm{g}$ cell protein were subjected to electrophoresis in $10 \%$ non-denaturing polyacrylamide gels containing $0.2 \%$ casein (Sigma), $0.1 \%$ SDS and $3.75 \mathrm{mU} / \mathrm{ml}$ bovine plasminogen (Sigma). After electrophoresis, gels were washed once in $2.5 \%$ Triton X100 for $45 \mathrm{~min}$ to remove SDS, and placed in incubation buffer $(50 \mathrm{mM}$ Tris, $0.1 \mathrm{M} \mathrm{NaCl}, \mathrm{pH} 7.6)$ at $37^{\circ} \mathrm{C}$ for $16 \mathrm{~h}$ with gentle shaking. The gels were then stained using
$0.05 \%$ Coomassie blue in $10 \%$ acetic acid, $40 \%$ methanol for $2 \mathrm{~h}$, destained in $10 \%$ acetic acid, $40 \%$ methanol, and then fixed in $10 \%$ glycerol. The identity of the enzymatic activities was investigated by comparing molecular size with human tPA (Calbiochem, Darmstadt, Germany) and uPA (NIBSC, Herts, UK) standards. Plasminogen-free gels were used to confirm that the activity detected was plasminogen dependent. Bands of plasmin activity were visualized as clear zones where casein degradation occurred, against a dark (blue) background. Images of gels were captured with an Alphalmager (Alpha Innotech Corp., San Leandro CA, USA), digitally inverted to give black proteolytic bands against a white background, and quantified with NIH Image software. To correct for gel-to-gel variation, all samples were expressed relative to a control sample (conditioned medium) that was included in every gel.

\section{Western blot}

$\mathrm{PN}-1$ protein abundance in $\mathrm{FF}$ and cell lysates was analyzed by Western blot as described (Cao et al. 2004). Samples were subjected to electrophoresis in 10\% denaturing polyacrylamide gels. Proteins were then electrotransferred onto nitrocellulose membrane $(0.45 \mu \mathrm{m})$ (Bio-Rad, Hercules, CA, USA) at $22 \mathrm{~V}$ overnight at $4{ }^{\circ} \mathrm{C}$ in transfer buffer $(39 \mathrm{mM}$ glycine, $48 \mathrm{mM}$ Tris-base, $0.037 \%$ SDS and 20\% methanol, $\mathrm{pH} 8.3$ ). After blocking for $1 \mathrm{~h}$ in TTBS $(0.2 \%$ Tween 20, $10 \mathrm{mM}$ Tris $-\mathrm{HCl}, 150 \mathrm{mM} \mathrm{NaCl})$, blots were incubated with 1:5000 rabbit anti-bovine PN-1 (Bédard et al. 2003) for $4 \mathrm{~h}$ with agitation, followed by three washes $(10 \mathrm{~min}$ each) with $0.2 \%$ TTBS. The blots were then incubated with 1:5000 alkaline phosphataselinked anti-rabbit IgG (Sigma) for $1.5 \mathrm{~h}$ with agitation, followed by three washes $(10 \mathrm{~min}$ each) with TTBS. Finally, the blots were incubated with NBT/BCIP solution (Roche Diagnostics, Indianapolis, IN, USA). Images of blots were captured with an Alphalmager and quantified with $\mathrm{NIH}$ Image software. Rainbow-colored protein molecular mass markers (Pharmacia, Piscataway, NJ, USA) were used to estimate molecular size of the target protein, and a bovine FF sample $(2 \mu \mathrm{l})$ was used as positive control in all blots.

\section{Steroid assays}

Estradiol and progesterone in FF from Experiment 2 were assayed by RIA using iodinated tracers and antibodies furnished in the 3rd Generation Estradiol RIA (DSL-39100) and the DSL-3400 Progesterone RIA kits (Diagnostic Systems Laboratories, Inc., Webster, TX, USA). The standard curves were prepared from crystalline steroids (Sigma) in PBS-gelatin (0.02 $\mathrm{M}$ sodium phosphate, $0.15 \mathrm{M}$ sodium chloride, $0.1 \%$ gelatin, $0.01 \%$ sodium azide, $\mathrm{pH} 7.5$ ). The assay protocols were as described in the kits, except that the estradiol antibody and tracer were each diluted 1:1 with PBS-gelatin before use, and the progesterone antibody and tracer were diluted 3:2 and 7:3 respectively. FF samples were diluted in PBS-gelatin before assay. 
Intra- and inter-assay coefficients of variation were 7.4 and $13.5 \%$ respectively for estradiol, and 6.8 and $7 \%$ respectively for progesterone. The sensitivities of the assays were $0.05 \mathrm{ng} / \mathrm{ml}$ for estradiol (at 1:25 dilution of FF) and $0.2 \mathrm{ng} / \mathrm{ml}$ for progesterone (at 1:10 dilution).

Concentrations of estradiol and progesterone in FF from Experiment 3 were analyzed by RIA using double antibody precipitation and charcoal absorption methods, as validated for use with bovine FF (Carrière \& Lee 1994, Price et al. 1995). Spiking FF samples with 2 pg/tube and $5 \mathrm{pg} /$ tube of estradiol gave 81 and $107 \%$ recovery respectively. Spiking FF samples with $100 \mathrm{pg} /$ tube and $500 \mathrm{pg} /$ tube of progesterone gave 115 and $97 \%$ recovery respectively. Intra- and inter-assay coefficients of variation were 5 and $10 \%$ for estradiol, and 7 and $8 \%$ for progesterone respectively.

\section{Statistics}

Data are presented as least-squares means \pm S.E.M. Data were transformed to logarithms when they were not normally distributed (Shapiro-Wilk test). All analyses were performed with JMP software (SAS Institute, Cary, NC, USA). The data from Experiments 1 and 2 were analyzed by ANOVA for effect of time (Experiment 1 ) or follicular class (Experiment 2), with gel or blot included as random effect terms where samples were analyzed in several gels/blots. Where main effects were found, means comparisons were performed by the Tukey-Kramer HSD test. In Experiment 3, data were analyzed by two-way ANOVA with follicular stage and rank as main effects. Owing to the lack of normal distribution of the estradiol data, log estradiol values were analyzed for effect of follicular rank within follicular stage. The time of follicular deviation was defined as the earliest change in diameter between the largest follicle (F1) and the second-largest follicle (F2). Correlations between PA activity or PN-1 secretion and FF steroid concentration or follicular diameter were assessed with Pearson's product-moment correlation coefficient $(r)$.

\section{Results}

\section{Experiment 1: $h C G$-induced periovulatory follicles}

PN-1, PAI-1, tPA and uPA mRNA expression were determined in follicular wall homogenates by RT-PCR. Abundance of mRNA encoding PN-1, PAI-1 and tPA all increased transiently after hCG injection $(P<0.05$; Fig. 1$)$, reaching maximal values at $6 \mathrm{~h}$ after hCG, and returning to pretreatment levels by $24 \mathrm{~h}$ after hCG injection. The pattern of uPA mRNA abundance differed from the other genes examined, as mRNA levels increased following hCG administration and remained elevated at $24 \mathrm{~h}$ after hCG injection ( $P<0.05$; Fig. 1C).
A
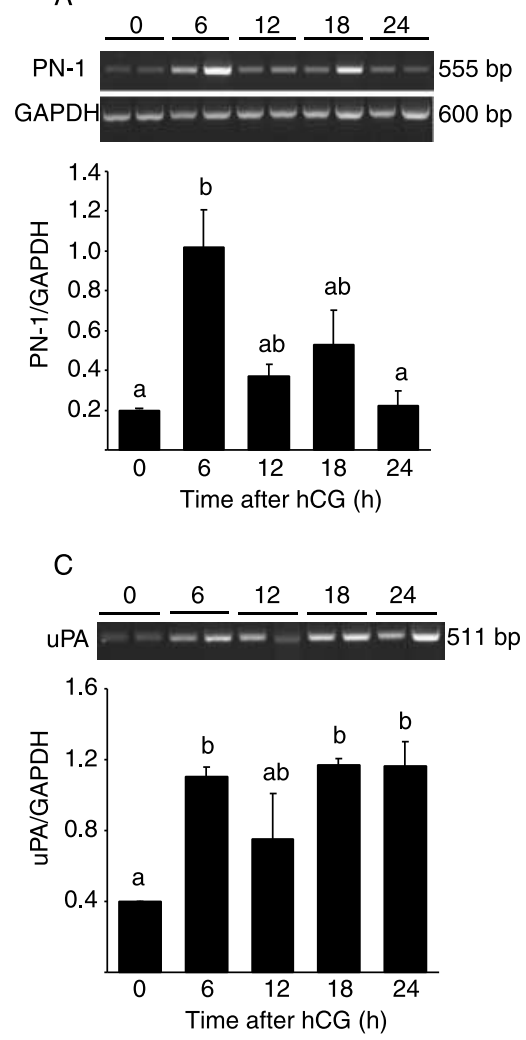

B
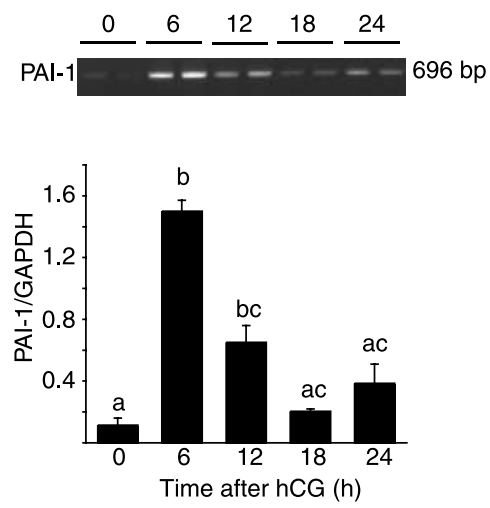

D

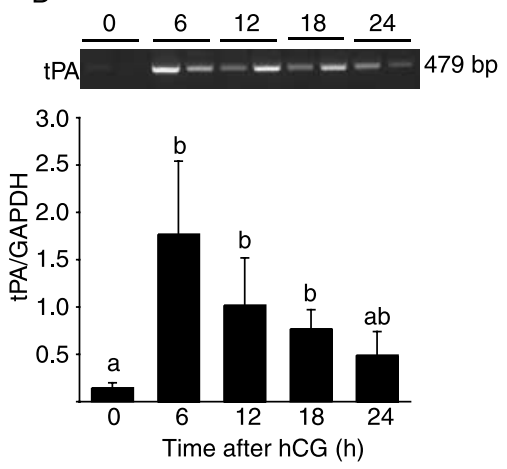

Figure 1 Analysis of (A) PN-1, (B) PAI-1, (C) uPA and (D) tPA mRNA expression in follicular wall lysates of preovulatory follicles by RT-PCR (Experiment 1). Total RNA was extracted from bovine preovulatory follicular walls collected at $0,6,12,18$ and $24 \mathrm{~h}$ after hCG injection, and was employed in mRNA expression analyses as described in Materials and Methods. GAPDH was used as a control gene, and showed no significant difference in expression levels between samples (A). Data are least-squares means (relative units) \pm S.E.M. of two animals. Different letters denote means that are significantly different $(P<0.05)$. 
A

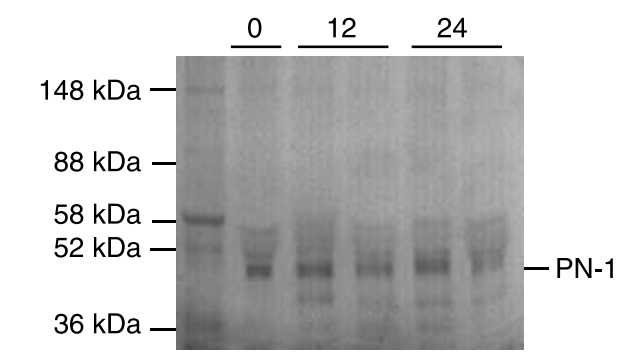

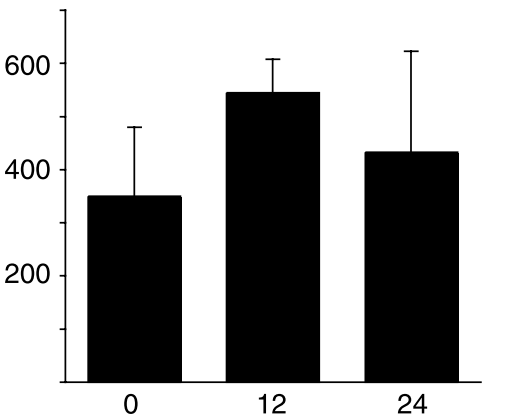

Time after hCG injection (h)

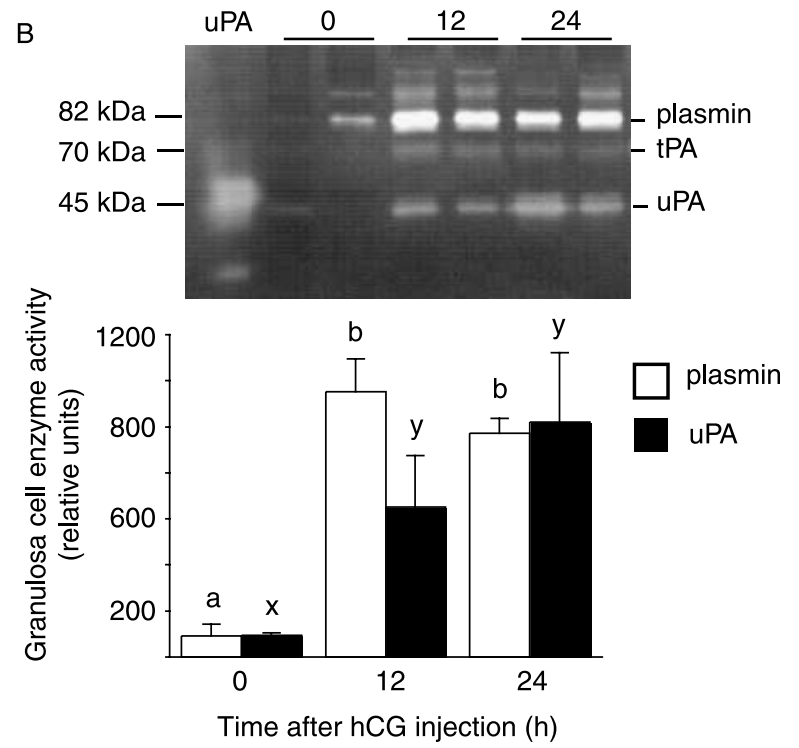

Figure 2 Analysis of (A) PN-1 protein content and (B) proteolytic enzyme activities in granulosa cell lysates from periovulatory bovine follicles at 0, 12 and $24 \mathrm{~h}$ after hCG (Experiment 1). For PN-1, samples $(50 \mu \mathrm{g}$ cell protein) were subjected to SDS-PAGE followed by blotting with an antibody raised against bovine PN-1. PA activity was measured in aliquots of $30 \mu \mathrm{g}$ cell protein by casein zymography. The zymograph presented in (B) shows lytic zones produced by human recombinant $\mathrm{UPA}$ standard (UPA) and samples collected at 0 , 12 and $24 \mathrm{~h}$ after hCG injection. Location of plasmin, tPA and uPA activities are indicated to the right of the zymograph. Different contrast and brightness settings were used for UPA and plasmin image capture, and although the data are plotted on the same axis, uPA activity was significantly weaker than plasmin activity. Data are leastsquares mean densitometry units \pm S.E.M. of two animals. For each enzyme, different letters denote means that are significantly different $(P<0.05)$.
To support the gene expression data, $\mathrm{PN}-1$ protein and PA activities in granulosa cell lysates were measured. A major immunoreactive band corresponding to PN-1 was detected by Western blot in granulosa cell lysates, and abundance of this protein band did not differ between 0 , 12 or $24 \mathrm{~h}$ after hCG injection (Fig. 2A). Zymography demonstrated an increase in proteolytic activity corresponding to plasmin (approximately $82 \mathrm{kDa}$ ) and uPA (approximately $45 \mathrm{kDa}$ ) in preovulatory granulosa cell lysates after hCG injection $(P<0.05$; Fig. 2B), whereas tPA activity was weak to undetected (Fig. 2B).
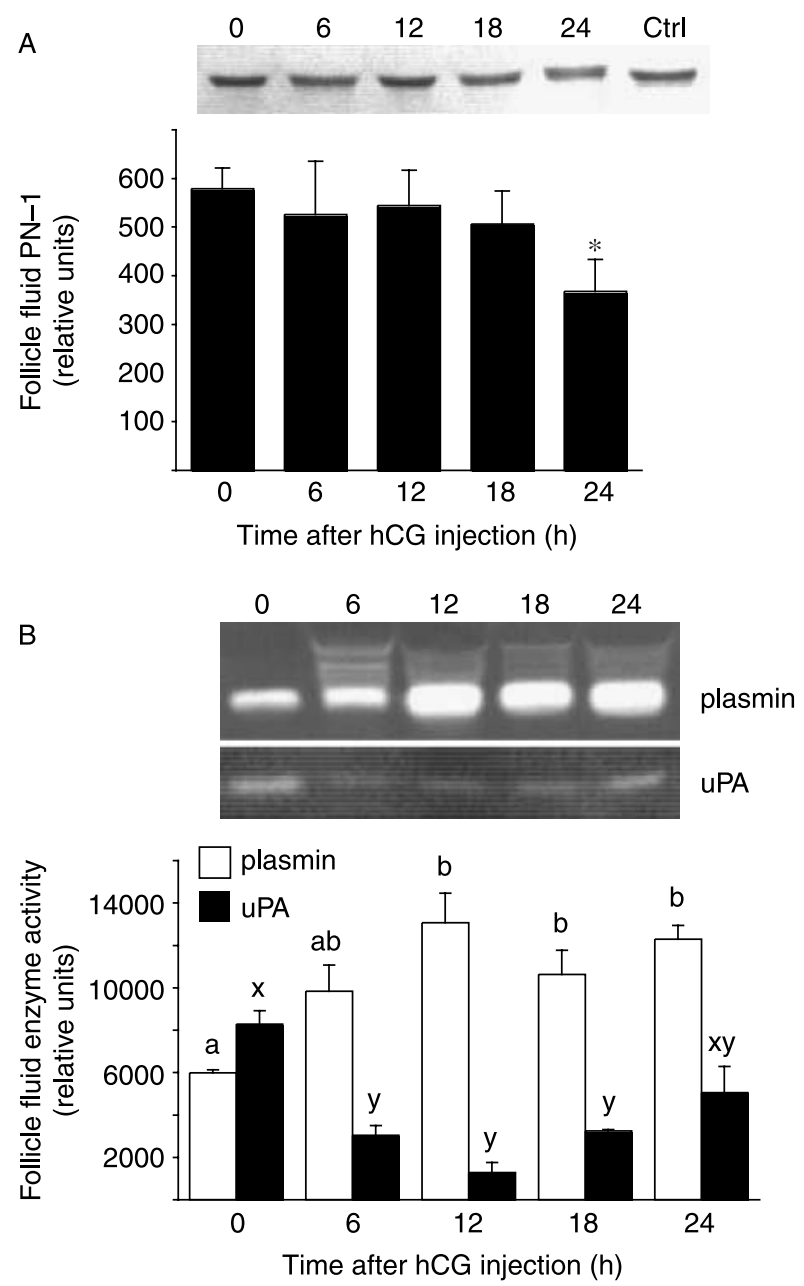

Figure 3 Analysis of (A) PN-1 protein content and (B) proteolytic enzyme activity in FF collected from periovulatory follicles at 0,6 , 12, 18 and $24 \mathrm{~h}$ after hCG (Experiment 1). The representative Western blot (for PN-1) and composite zymograph (for uPA and plasmin activity) presented show data for one animal at each time point, plus the control (Ctrl) sample (FF) used in Western blotting. Image-capture parameters for plasmin and uPA activity were different owing to the significantly weaker uPA activity. Results shown represent leastsquares means \pm S.E.M. densitometry units of two animals. For each enzyme, bars with different letters are significantly different $(P<0.05)$; *mean different from time $0(P<0.05)$. 
Table 2 Estradiol and progesterone concentrations, and mean diameters of follicles in non-atretic, early-atretic and atretic follicles in Experiment 2.

\begin{tabular}{lccr}
\hline Follicle class & Diameter $(\mathrm{mm}($ range $))$ & Estradiol $(\mathrm{ng} / \mathrm{ml}($ range $))$ & Progesterone $(\mathrm{ng} / \mathrm{ml}($ range) \\
\hline Non-atretic $(n=7)$ & $11.6 \pm 0.8^{\mathrm{a}}(10-14)$ & $1392 \pm 687^{\mathrm{a}}(396-4084)$ & $33 \pm 2^{\mathrm{a}}(28-38)$ \\
Early-atretic $(n=7)$ & $9.7 \pm 0.6^{\mathrm{a}}(9-13)$ & $1.3 \pm 0.6^{\mathrm{b}}(0.6-4.6)$ & $34 \pm 6^{\mathrm{a}}(18-63)$ \\
Atretic $(n=4)$ & $10.0 \pm 0.6^{\mathrm{a}}(9-11)$ & $13 \pm 8^{\mathrm{b}}(0.4-31.0)$ & $207 \pm 86^{\mathrm{b}}(106-465)$ \\
\hline
\end{tabular}

For each variable, means with different superscripts are significantly different $(P<0.05)$.

FF PN-1 protein content decreased with time after hCG injection, reaching the lowest levels at $24 \mathrm{~h}$ after $\mathrm{hCG}$ $(P<0.05 ;$ Fig. 3A). Plasmin activity in FF increased after hCG $(P<0.05$; Fig. 3B) whereas uPA activity decreased (Fig. 3B). Proteolytic activity corresponding to tPA was not detected in FF of preovulatory follicles.

\section{Experiment 2: healthy and atretic large follicles}

Estradiol and progesterone concentrations and diameters of the follicles in each class are given in Table 2. Non-atretic and early-atretic differed by estradiol content but not by progesterone content or diameter; non-atretic and atretic follicles differed by estradiol and progesterone content, but not by follicular diameter. Plasmin activity in FF collected from non-atretic follicles was significantly lower than that in early-atretic and atretic follicles $(P<0.05$; Fig. 4A). uPA activity in FF did not differ between groups (Fig. 4A). tPA activity was not detected in any the follicles examined. PN-1 protein abundance in FF of non-atretic follicles was significantly higher than that of early-atretic and atretic follicles $(P<0.05$; Fig. 4B). Plasmin activity in FF was negatively correlated with $\mathrm{PN}-1$ content $(r=-0.6$, $P<0.05)$ but not with uPA activity $(P>0.05)$.

mRNA for TPA, UPA, and PN-1 was detected in granulosa cells. PN-1 mRNA levels were lower in granulosa cells of early-atretic follicles than in those of non-atretic and atretic follicles $(P<0.05$; Fig. $5 \mathrm{~A})$, but there were no differences in tPA or UPA mRNA levels. mRNA for tPA, UPA and PAI-1 was detected in theca cells, and message levels did not differ significantly between groups (Fig. 5B).

Overall, granulosa cell PN-1 mRNA abundance and FF $\mathrm{PN}-1$ protein abundance were positively correlated with FF estradiol concentrations $(r=0.73$ and 0.62 respectively, $P<0.01)$. Plasmin activity in FF was negatively correlated with FF estradiol concentration $(r=-0.65$, $P<0.01)$. Follicular diameter was correlated with granulosa cell tPA mRNA abundance $(r=0.57, P<0.05)$ but with no other variable.

\section{Experiment 3: early in the follicular wave}

Mean diameters and estradiol and progesterone concentrations in the F1, F2 and F3 follicles are summarized in Table 3. A significant difference in diameter between the largest (F1) and second-largest (F2) follicle occurred when the F1 had reached $9.5 \mathrm{~mm}$. Estradiol concentrations did not differ between the three largest follicles of a wave when the F1 was $6.5 \mathrm{~mm}$ diameter, but was significantly lower in the F3 compared with F1 at all subsequent stages. Differences in estradiol between F1 and F2 occurred only after follicular deviation. Progesterone concentrations did not differ between follicles at any stage of the wave. Based on the follicular health criteria used in Experiment 2, all F3 and three F2 follicles in the $7.5 \mathrm{~mm}$ group, all F3 and two F2 follicles in the $8.5 \mathrm{~mm}$ group, and all F3 and all F2 follicles in the $9.5 \mathrm{~mm}$ group were early-atretic.

A single band corresponding to $\mathrm{PN}-1$ was detected in $\mathrm{FF}$ by immunoblotting, and PN-1 abundance did not significantly change with stage of the follicular wave or between F1, F2 or F3 follicles (Fig. 6A). Plasmin and uPA (but not tPA) activities were detected in FF, and no differences were observed between follicular stages or rank (Fig. 6B). However, uPA activity was correlated with FF estradiol concentration (not shown) and the estradiol:progesterone ratio (Fig. 7) in subordinate but not in dominant (F1) follicles.

\section{Discussion}

The pattern of expression and potential role of $\mathrm{PN}-1$ during follicular growth is not well known. In the present study, we measured PN-1 and PA activity in bovine follicles at three stages of follicular development. We demonstrate that during the periovulatory period the expression of $\mathrm{PN}-1$ is initially upregulated by hCG, and then declines in a pattern similar to the expression of PAI- 1 and tPA. This profile of $\mathrm{PN}-1$ expression appears to differ from that observed in rodents, where no change in expression was observed until the onset of ovulation (Hägglund et al. 1996, Hasan et al. 2002), although these are in situ studies that do not lend themselves well to quantification. We also demonstrate a potential role for PN-1 in dominant follicular growth, as follicular protein levels are higher in non-atretic than in early-atretic and atretic follicles.

We first measured the pattern of expression of PA system members in the follicle wall in response to an ovulatory dose of hCG, as the ovarian PA system is best known for its role during ovulation. Follicular PAA, uPA, PAI-1 and $\mathrm{PN}-1$ mRNA abundance increased sharply by $6 \mathrm{~h}$ after hCG, and mRNA levels declined thereafter, except for uPA mRNA, which remained high until the expected time of ovulation. Overall, these results support previous 
A

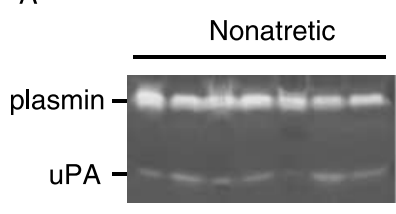

Follicle class
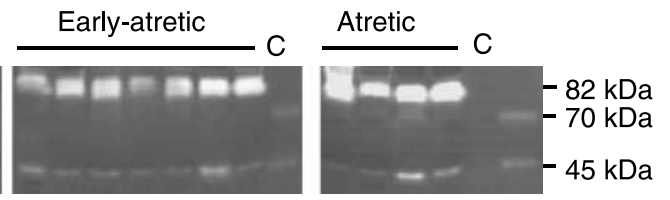

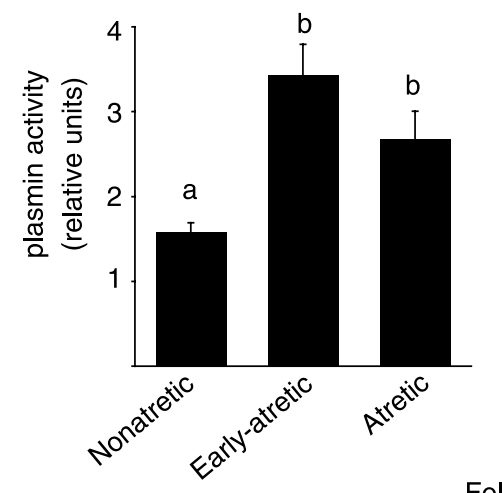

Follicle class

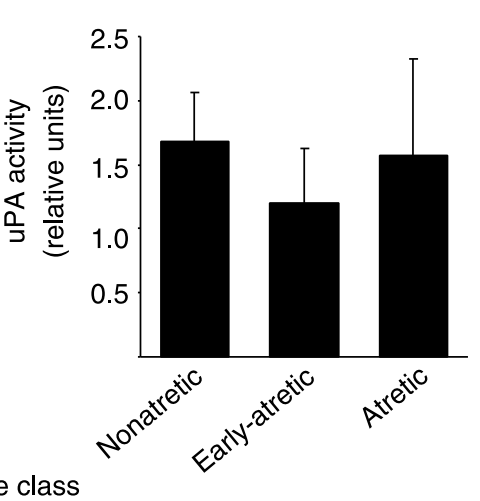

Follicle class

B Nonatretic
Early-atretic

C Atretic

\section{C}

\section{PN-1 UE}

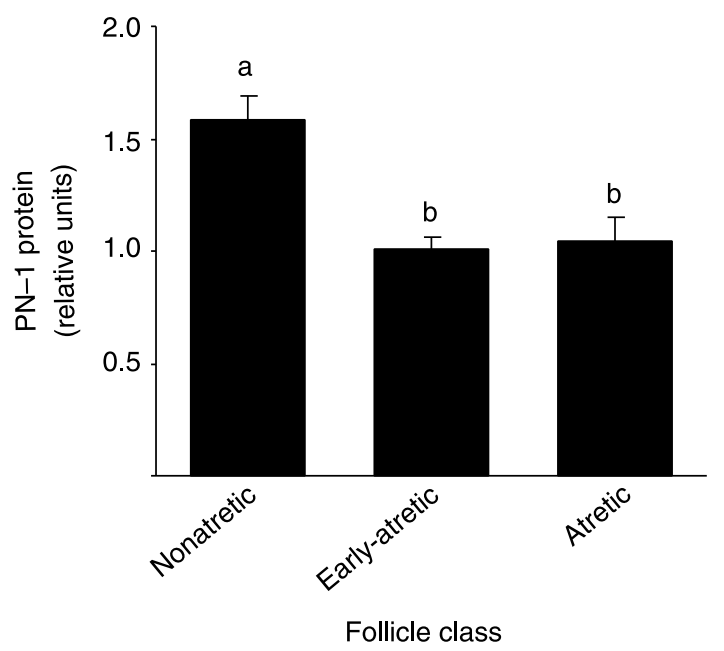

Figure 4 Plasmin and uPA enzyme activities (A) and $\mathrm{PN}-1$ protein $(\mathrm{B})$ in FF from non-atretic $(n=7)$, early-atretic $(n=7)$ and atretic $(n=4)$ follicles (Experiment 2). Follicular classification is described in Materials and Methods. Inserts are zymographs (A) and Western blots (B) showing raw data for all follicles. Lanes marked ' $C$ ' are control samples used to correct for variation between gels. Data are leastsquares means (relative units) \pm S.E.M. Bars with different letters are significantly different $(P<0.05)$. studies in cattle (Dow et al. 2002a, 2002b), in which tPA, UPA and PAI-1 mRNA levels were upregulated by an induced gonadotropin surge. This is in contrast to that observed in other species, in which only one PA was increased in response to the gonadotropin surge. For instance, only tPA in rats (Li et al. 1997) and monkeys (Liu et al. 2004) or uPA in mice (Macchione et al. 2000) and sheep (Colgin \& Murdoch 1997) was upregulated during ovulation. The specific time points when mRNA abundance increased and then decreased is slightly different between the present study and the previous studies (Dow et al. 2002a,b), possibly caused by the different methods of inducing ovulation (hCG vs gonadotropin-releasing hormone $(\mathrm{GnRH}))$.
Changes in periovulatory $\mathrm{PN}-1$ expression have not previously been described in ruminants. In mice, granulosa cell $\mathrm{PN}-1$ expression generally did not vary throughout the periovulatory period (Hägglund et al. 1996), although a decrease in immunostaining was observed $12 \mathrm{~h}$ after hCG injection in PMSG-stimulated rats (Hasan et al. 2002). The present data clearly show a transient upregulation of $\mathrm{PN}-1$ expression within $6 \mathrm{~h}$ of hCG treatment, indicating that $\mathrm{PN}-1$ regulation in cattle is different from that of rodents. The only comparable work in ruminants is a gene-profiling study that described lower PN-1 expression in periovulatory follicles $24 \mathrm{~h}$ after hCG injections compared with dominant non-ovulatory follicles on day 5 of the estrous cycle 


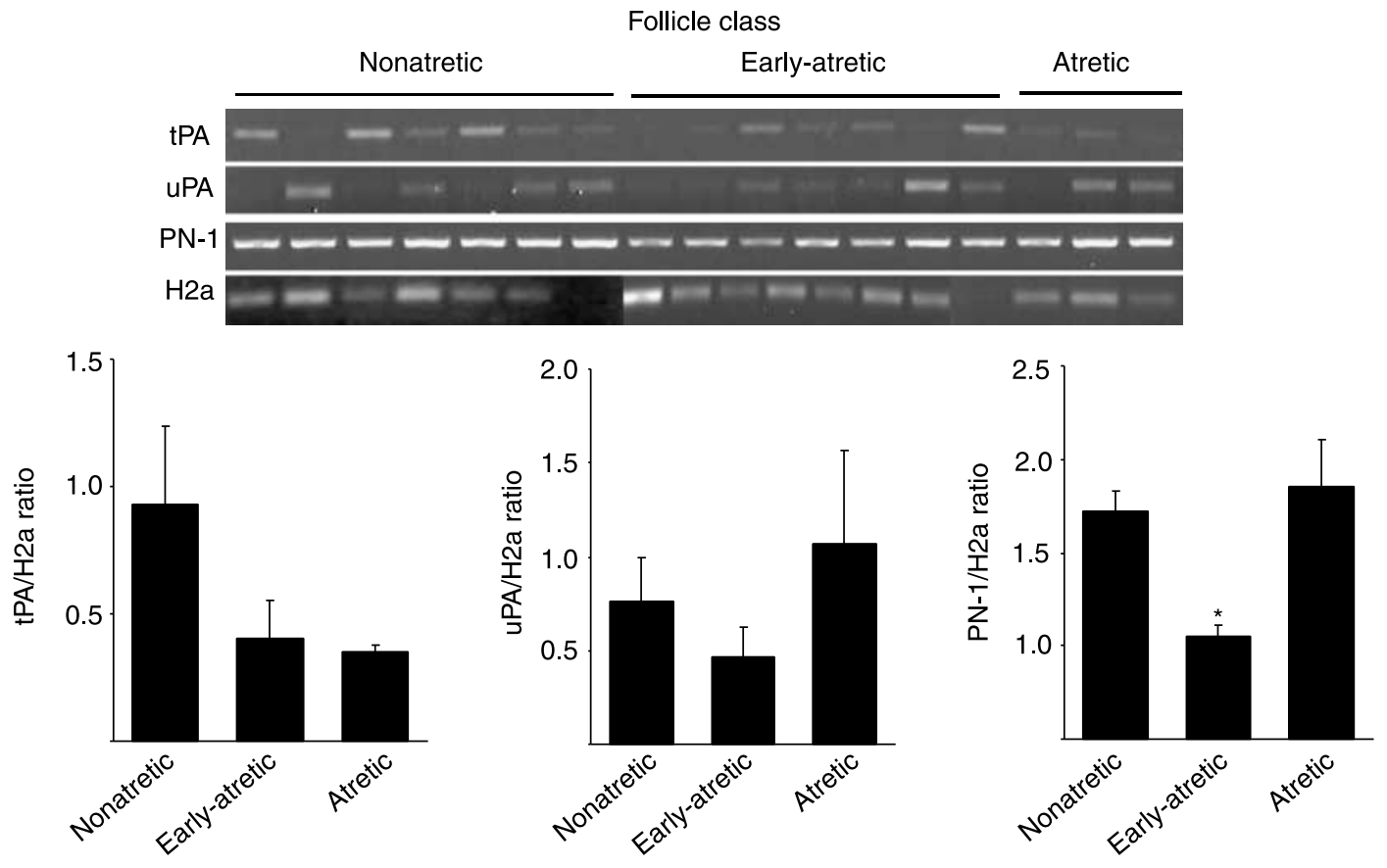

Follicle class

B Theca cells
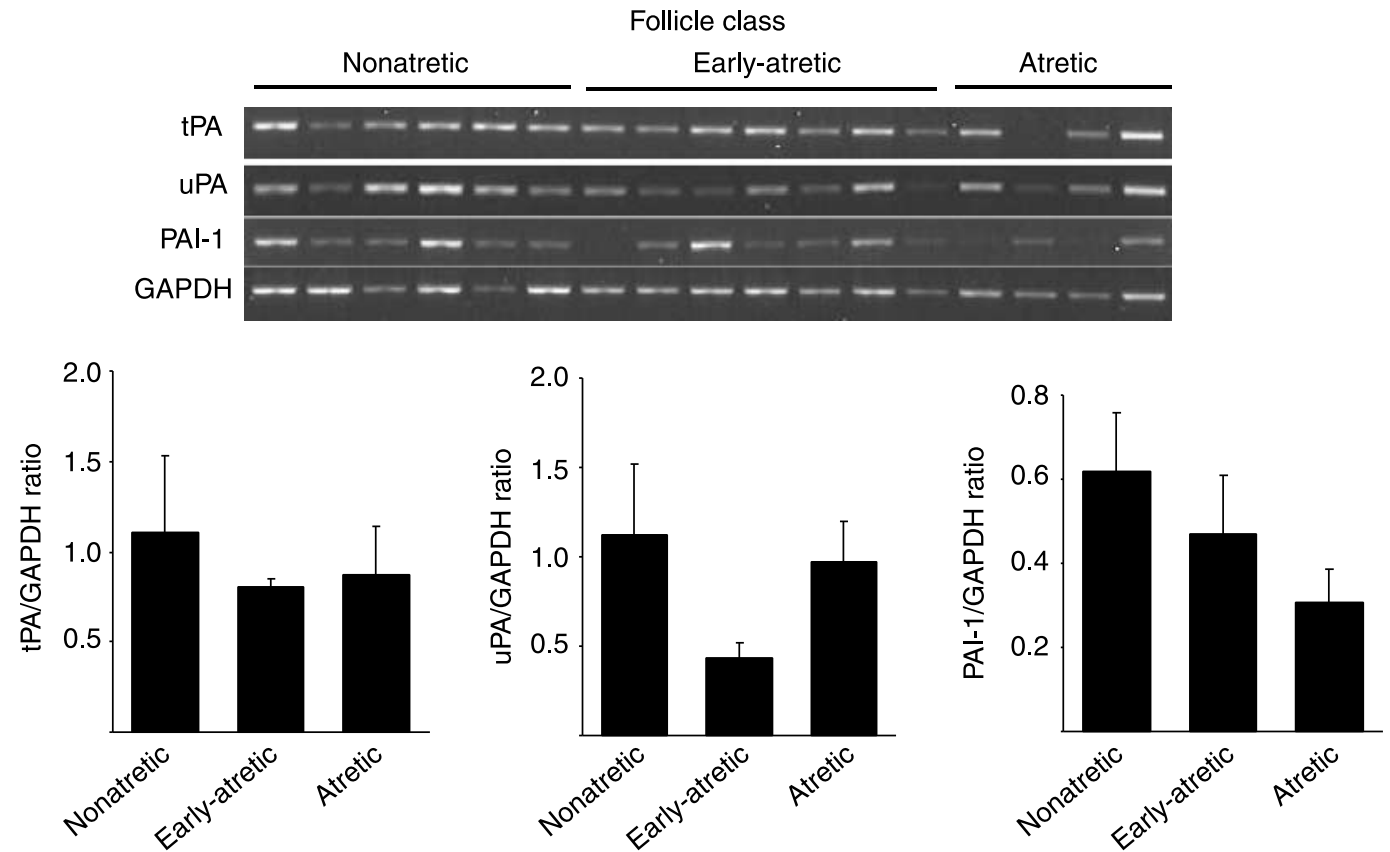

Follicle class

Figure 5 RT-PCR analysis of mRNA expression of PA and PA inhibitors in (A) granulosa and (B) theca cells from non-atretic $(n=7)$, early-atretic $(n=7)$ and atretic $(n=4)$ follicles (Experiment 2). Follicular classification is described in Materials and Methods. Inserts are composite images of agarose gels showing all samples. Data are least-squares means (relative units) \pm S.E.M. Group means that differed are indicated by an asterisk $(P<0.05)$ 
Table 3 Mean \pm S.E.M. diameter and FF steroid content of the dominant (F1) and the two largest subordinate follicles (F2, F3) collected early in a follicular wave, when the dominant follicle reached approximately 6.5, 7.5, 8.5 or $9.5 \mathrm{~mm}$ diameter Experiment.

\begin{tabular}{llccc}
\hline $\begin{array}{l}\text { Follicle stage } \\
(\mathrm{mm})\end{array}$ & Follicle rank & $\begin{array}{c}\text { Diameter } \\
(\mathrm{mm})\end{array}$ & $\begin{array}{c}\text { Estradiol } \\
(\mathrm{ng} / \mathrm{ml})+\end{array}$ & $\begin{array}{c}\text { Progesterone } \\
(\mathrm{ng} / \mathrm{ml})\end{array}$ \\
\hline 6.5 & F1 & $6.5 \pm 0.1$ & $114 \pm 33$ & $29 \pm 6$ \\
& F2 & $6.1 \pm 0.3$ & $68 \pm 17$ & $30 \pm 8$ \\
& F3 & $5.6 \pm 0.3$ & $40 \pm 18$ & $61 \pm 41$ \\
7.5 & F1 & $7.4 \pm 0.1$ & $226 \pm 42^{\mathrm{a}}$ & $37 \pm 8$ \\
& F2 & $6.5 \pm 0.1$ & $127 \pm 51^{\mathrm{ab}}$ & $29 \pm 6$ \\
& F3 & $5.7 \pm 0.2$ & $32 \pm 6^{\mathrm{b}}$ & $23 \pm 5$ \\
8.5 & F1 & $8.2 \pm 0.5$ & $423 \pm 124^{\mathrm{a}}$ & $30 \pm 6$ \\
& F2 & $6.8 \pm 0.6$ & $168 \pm 68^{\mathrm{a}}$ & $26 \pm 4$ \\
& F3 & $6.4 \pm 0.6$ & $14 \pm 10^{\mathrm{b}}$ & $60 \pm 28$ \\
9.5 & F1 & $9.7 \pm 0.1 *$ & $682 \pm 45^{\mathrm{a}}$ & $46 \pm 6$ \\
& F2 & $6.8 \pm 0.3$ & $3 \pm 1^{\mathrm{b}}$ & $74 \pm 43$ \\
& F3 & $6.1 \pm 0.1$ & $11 \pm 8^{\mathrm{b}}$ & $19 \pm 5$ \\
\hline
\end{tabular}

† Within follicle stage group, different superscripts denote differences between F1, F2 and F3 follicles $(P<0.05)$.

*F1 follicle was significantly different from F2 follicle. $n=7$ follicles/group.

(Bédard et al. 2003). In rats, a model was proposed for the tight regulation of proteolytic activity in periovulatory follicles, in which both tPA and PAI-1 expression increase initially to generate high levels of inhibited enzyme within the follicular wall (Liu et al. 1987, Shen et al. 1997). According to this model, PAI-1 but not tPA expression then decreases, thus triggering activation of accumulated tPA and degradation of the follicular wall. In cattle, a modified version of this model can be proposed, in which there is an initial upregulation of tPA, uPA, PAI-1 and PN-1, followed by a decrease in tPA, PAI-1 and PN-1 expression while maintaining uPA expression. The activation of accumulated PA in theca (owing to reduced PAI-1 expression) and granulosa (owing to reduced $\mathrm{PN}-1$ expression) cells would contribute to the proteolytic cascade at ovulation in this species. The cell-specific expression of PA inhibitors is physiologically relevant, as tPA expression is localized predominantly to the granulosa layer in bovine follicles (Dow et al. 2002a), thus regulation of PN-1 expression is probably important to prevent precocious proteolytic activity on the antral side of the basal lamina.

This model for the control of the proteolytic cascade at ovulation in cattle is supported by the increased uPA and plasmin activity in granulosa cell lysates observed 12-24 h after hCG, at a time when granulosa cell PN1 protein levels were not different from pretreatment controls (see Fig. 2). The increase in plasmin activity in granulosa cells was reflected by an increase in FF plasmin activity. This is consistent with the plasmin activity detected in sheep follicular walls (Murdoch 1998), but in contrast to a previous study in cattle (Dow et al. 2002a) in which FF plasmin activity increased in
GnRH-treated animals, but was not detected in the lysates of whole follicular wall. The reason for this discrepancy is unknown but may be related to the methods used to prepare lysate samples and/or the use of whole follicular wall compared with granulosa cells. We also observed an increase in uPA activity in granulosa cell lysates after hCG but a decrease in activity in FF. This discrepancy may be caused by a redistribution of UPA to the cell surface or the ECM (Macchione et al. 2000) or specific regulation of protein secretion, or be a consequence of changes in thecal contribution to total FF levels of uPA.

The expression of $\mathrm{PN}-1$ has been detected in small antral follicles (Hägglund et al. 1996, Hasan et al. 2002, Bédard et al. 2003) suggesting that it might play a role in follicular growth prior to the preovulatory period. We explored this by measuring PN-1 and PA activity/expression in non-atretic and atretic dominant follicles, and during follicular deviation early in the follicular wave. Changes in $\mathrm{PN}-1$ or PA activity in FF were not detected during the growth of the follicular cohort before deviation, even though FF estradiol content increased in the largest follicle and decreased in smaller follicles of the cohort. Interestingly, uPA activity in FF was positively correlated with follicular estradiol content in subordinate follicles early in a follicular wave but not in the largest, presumably dominant follicle of the cohort. This suggests that the estrogenic subordinate follicles may be growing or have the potential to grow, and may have different requirements for uPA activity than the less-estrogenic subordinate follicles whose growth may have ceased. In support of this, it has been demonstrated that larger subordinate follicles have the capacity to develop into dominant follicles if the existing dominant follicle is ablated (Ginther et al. 2001a). The dominant follicle is actively growing and therefore would be expected to undergo constant ECM remodeling irrespectively of estradiol content, which might explain the absence of a correlation between estradiol and UPA in the dominant follicle. The absence of changes in $\mathrm{PN}-1$ protein or expression in pre-deviation follicles suggests that $\mathrm{PN}-1$ may not be tightly regulated prior to deviation, or may not play a role at this stage of development.

In dominant follicles, however, $\mathrm{PN}-1$ may be regulated and/or play a more important role. FF PN-1 content was lower in early-atretic and atretic follicles compared with non-atretic follicles, and FF plasmin activity was correspondingly higher in the early-atretic and atretic follicles. Plasmin activity in FF appears to be regulated by $\mathrm{PN}-1$, as plasmin activity was correlated with PN-1 but not UPA, and UPA activity did not change significantly with follicular health. PN-1 has been suggested to be an anti-apoptotic factor in adherent cells, as it inhibited plasminogen activation-induced anoikis in these cells (Rossignol et al. 2004). Atresia in dominant bovine follicles is characterized by apoptosis 
A

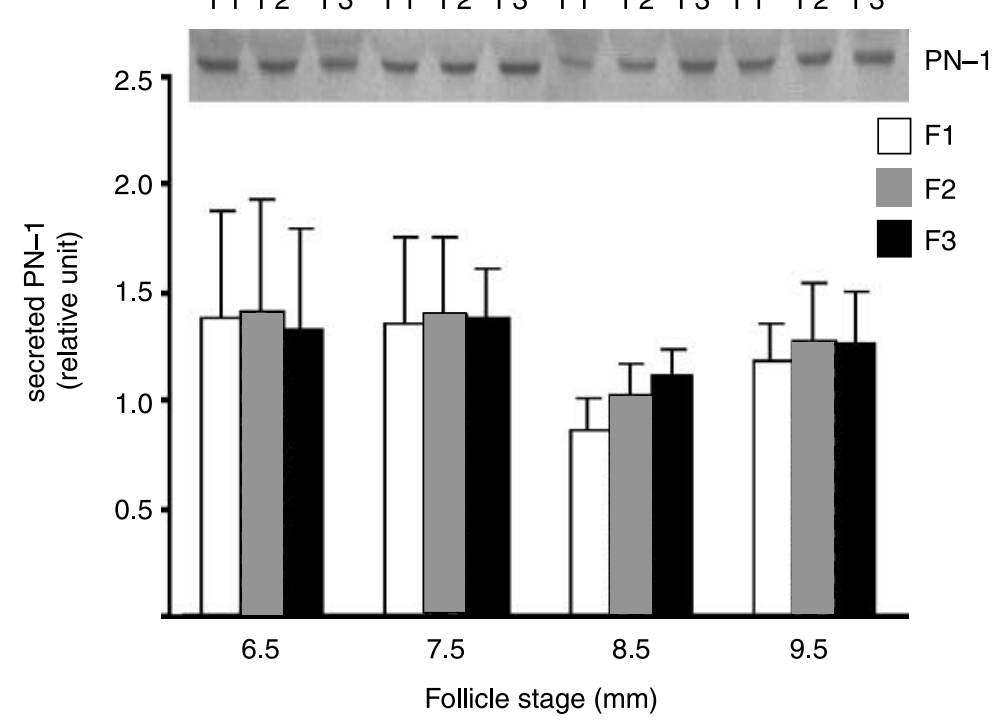

B

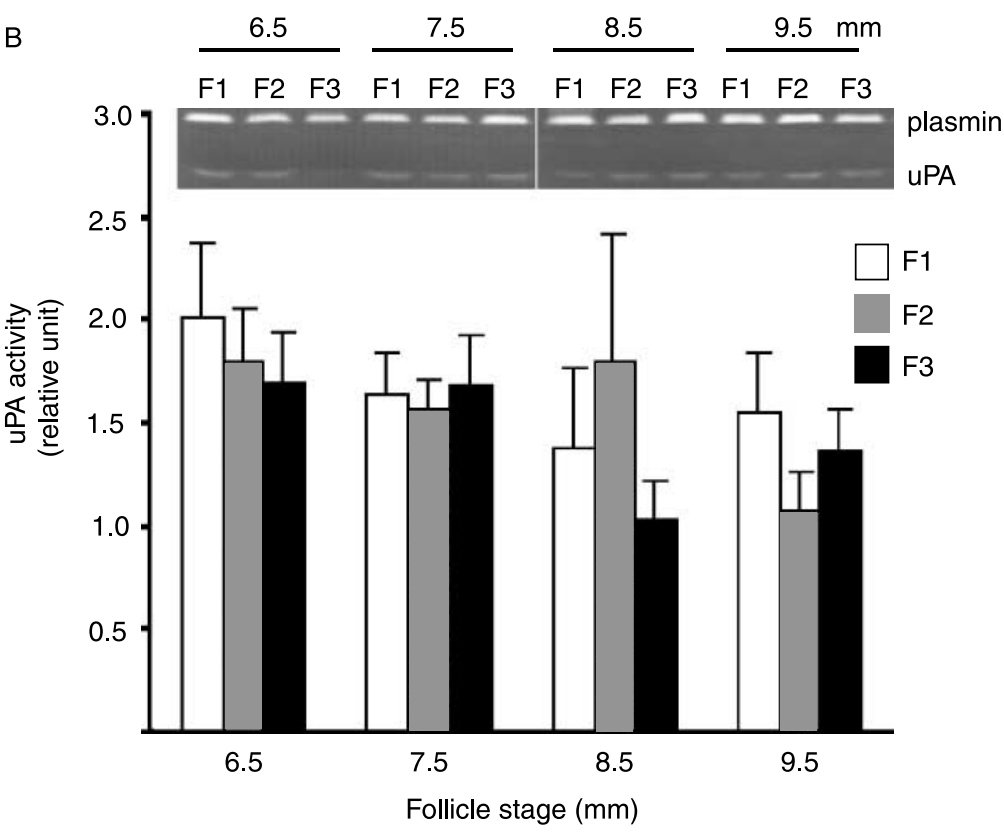

$6.5 \quad \frac{7.5}{8.5} \frac{9.5 \mathrm{~mm}}{\mathrm{~F} 1 \mathrm{F2}}$

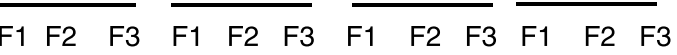

Figure $6 \mathrm{PN}-1$ protein $(\mathrm{A})$ and uPA enzyme activity (B) in FF samples collected from growing dominant (F1) and subordinate (F2, F3) follicles during the first follicular wave (Experiment 3). FF was collected by ultrasoundguided aspiration when the dominant follicle reached approximately $6.5,7.5,8.5$ and $9.5 \mathrm{~mm}$ diameter (follicle stage). Inserts are representative Western blots (A) and zymographs (B). Data are least-squares means (relative units) \pm S.E.M. of seven animals at each follicular stage. and detachment of granulosa cells near the antrum (Irving-Rodgers et al. 2001), and in sheep there are changes in collagen and fibronectin content of earlyatretic follicles (Huet et al. 1998). Therefore it is possible that certain endocrine or paracrine signals may inhibit PN-1 synthesis and/or secretion from dominant follicles at the end of their growth phase, and these lowered PN-1 levels may be involved in the process of atresia in the membrana granulosa.

In summary, PN-1 expression/secretion changes in a manner dependent on stage of follicular development. Specifically, no changes in PN-1 or PA activity were observed during the growth of follicles early in the follicular wave before follicular deviation occurred, suggesting a minor role, if any, for these proteins before follicular deviation. In dominant follicles, however, $\mathrm{PN}-1$ levels in FF were lower in atretic compared with non-atretic dominant follicles, and were inversely correlated with follicular plasmin activity. We suggest that $\mathrm{PN}-1$ may be involved in atresia in non-ovulatory dominant follicles. In periovulatory follicles, PN-1, PAI-1, tPA and uPA mRNA levels were transiently upregulated by hCG, and all decreased at the expected time of ovulation except for UPA, which remains elevated. These data suggest a role for $\mathrm{PN}$-1 in preventing precocious proteolysis in the granulosa cell layer before ovulation. 

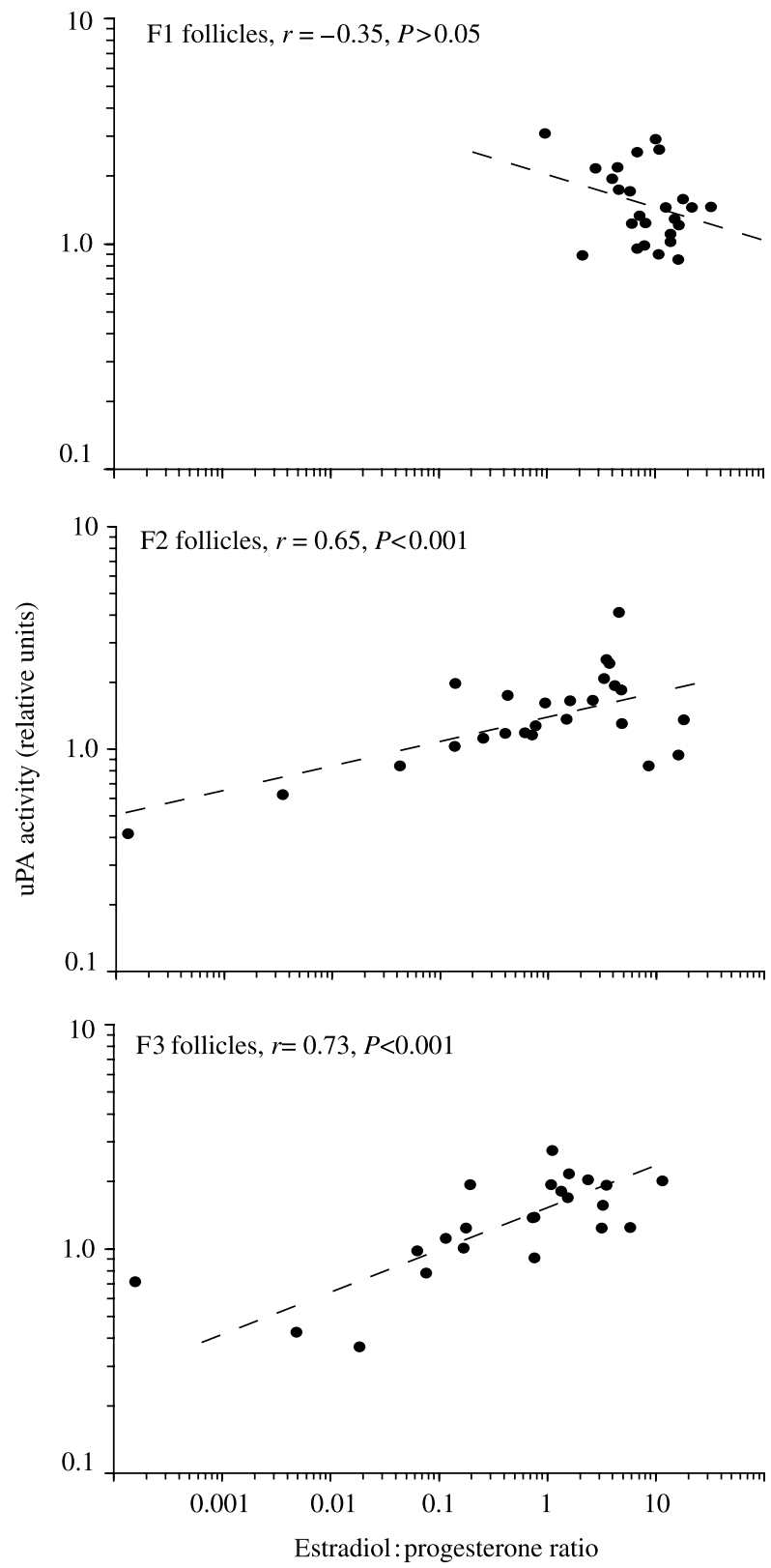

Figure 7 Correlation between estradiol:progesterone ratio and uPA activity in FF from growing dominant (F1) and subordinate (F2, F3) follicles during the first follicular wave (Experiment 3). FF was collected by ultrasound-guided aspiration when the dominant follicle reached approximately $6.5,7.5,8.5$ and $9.5 \mathrm{~mm}$ diameter (follicular stage). Each data point represents an individual follicle, and correlation coefficients are given for each follicular rank

\section{Acknowledgements}

We thank Drs A K Goff and A Bélanger for steroid antibodies. Special thanks to Drs Jean Sirois, Yan Ouellette and Andrey Borges Teixeira for help with follicular collection and FF steroid assays. This work was supported by NSERC (Canada), FQRNT (Québec) and FAPESP (São Paulo). The authors declare that there is no conflict of interest that would prejudice the impartiality of this scientific work.

\section{References}

Balcerzak D, Querengesser L, Dixon WT \& Baracos VE 2001 Coordinate expression of matrix-degrading proteinases and their activators and inhibitors in bovine skeletal muscle. Journal of Animal Science 79 94-107.

Bédard J, Brûlé S, Price CA, Silversides DW \& Lussier JG 2003 Serine protease inhibitor-E2 (SERPINE2) is differentially expressed in granulosa cells of dominant follicles in cattle. Molecular Reproduction and Development 64 152-165.

Beg MA, Bergfelt DR, Kot K, Wiltbank MC \& Ginther OJ 2001 Follicular-fluid factors and granulosa-cell gene expression associated with follicle deviation in cattle. Biology of Reproduction 64 432-441.

Buratini J Jr, Teixeira AB, Costa IB, Glapinski VF, Pinto MGL, Giometti IC, Barros CM, Cao M, Nicola ES \& Price CA 2005 Expression of fibroblast growth factor- 8 and regulation of cognate receptors, fibroblast growth factor receptor (FGFR)-3c and -4 , in bovine antral follicles. Reproduction $130343-350$.

Cao M, Sahmi M, Lussier JG \& Price CA 2004 Plasminogen activator and serine protease inhibitor-E2 (protease nexin-1) expression by bovine granulosa cells in vitro. Biology of Reproduction 71 887-893.

Carrière PD \& Lee B 1994 Direct radioimmunoassay of progesterone in bovine plasma using danazol (17-alpha-2,4-pregnadien-20yno(2,3-d)isoxazol-17-ol) as a displacing agent. Canadian Journal of Veterinary Research 58 230-233.

Chomczynski P \& Sacchi N 1987 Single-step method of RNA isolation by acid guanidinium thiocyanate-phenol-chloroform extraction. Analytical Biochemistry 162 156-159.

Colgin DC \& Murdoch WJ 1997 Evidence for a role of the ovarian surface epithelium in the ovulatory mechanism of the sheep: secretion of urokinase-type plasminogen activator. Animal Reproduction Science 47 197-204.

Curry TE Jr, Song L \& Wheeler SE et al. 2001 Cellular localization of gelatinases and tissue inhibitors of metalloproteinases during follicular growth, ovulation, and early luteal formation in the rat. Biology of Reproduction 65 855-865.

Dow MP, Bakke LJ, Cassar CA, Peters MW, Pursley JR \& Smith GW 2002a Gonadotropin surge-induced up-regulation of the plasminogen activators (tissue plasminogen activator and urokinase plasminogen activator) and the urokinase plasminogen activator receptor within bovine periovulatory follicular and luteal tissue. Biology of Reproduction 66 1413-1421.

Dow MP, Bakke LJ, Cassar CA, Peters MW, Pursley JR \& Smith GW $2002 b$ Gonadotrophin surge-induced upregulation of mRNA for plasminogen activator inhibitors 1 and 2 within bovine periovulatory follicular and luteal tissue. Reproduction 123 711-719.

Fayad T, Levesque V, Sirois J, Silversides DW \& Lussier JG 2004 Gene expression profiling of differentially expressed genes in granulosa cells of bovine dominant follicles using suppression subtractive hybridization. Biology of Reproduction 70 523-533.

Fortune JE, Rivera GM, Evans AC \& Turzillo AM 2001 Differentiation of dominant versus subordinate follicles in cattle. Biology of Reproduction $\mathbf{6 5}$ 648-654.

Ginther OJ, Bergfelt DR, Beg MA \& Kot K 2001a Follicle selection in cattle: relationships among growth rate, diameter ranking, and capacity for dominance. Biology of Reproduction 65 345-350.

Ginther OJ, Beg MA, Bergfelt DR, Donadeu FX \& Kot K 2001b Follicle selection in monovular species. Biology of Reproduction $\mathbf{6 5}$ 638-647

Hägglund AC, Ny A, Liu K \& Ny T 1996 Coordinated and cellspecific induction of both physiological plasminogen activators creates functionally redundant mechanisms for plasmin formation during ovulation. Endocrinology $1375671-5677$.

Hasan S, Hosseini G, Princivalle M, Dong JC, Birsan D, Cagide C \& de Agostini Al 2002 Coordinate expression of anticoagulant heparan sulfate proteoglycans and serine protease inhibitors in the rat ovary: a potent system of proteolysis control. Biology of Reproduction 66 144-158. 
Huet C, Monget P, Pisselet C, Hennequet C, Locatelli A \& Monniaux D 1998 Chronology of events accompanying follicular atresia in hypophysectomized ewes. Changes in levels of steroidogenic enzymes, connexin 43, insulin-like growth factor $11 /$ mannose 6 phosphate receptor, extracellular matrix components, and matrix metalloproteinases. Biology of Reproduction 58 175-185.

Irving-Rodgers HF, van Wezel IL, Mussard ML, Kinder JE \& Rodgers RJ 2001 Atresia revisited: two basic patterns of atresia of bovine antral follicles. Reproduction 122 761-775.

Karakji EG \& Tsang BK 1995 Follicular stage-dependent regulation of rat granulosa cell plasminogen activator system by transforming growth factor-alpha in vitro. Biology of Reproduction $\mathbf{5 2}$ 411-418.

Li J, Croze F, Yan W, Hache RJ \& Tsang BK 1997 Up-regulation of urokinase plasminogen activator messenger ribonucleic acid and protein in hen granulosa cells by transforming growth factor alpha in vitro during follicular development. Biology of Reproduction $\mathbf{5 6}$ $1317-1322$

Liu YX 2004 Plasminogen activator/plasminogen activator inhibitors in ovarian physiology. Frontiers in Bioscience 9 3356-3373.

Liu YX, Cajander SB, Ny T, Kristensen P \& Hsueh AJ 1987 Gonadotropin regulation of tissue-type and urokinase-type plasminogen activators in rat granulosa and theca-interstitial cells during the periovulatory period. Molecular and Cellular Endocrinology 54 $221-229$.

Liu YX, Liu K, Feng Q, Hu ZY, Liu HZ, Fu GQ, Li YC, Zou RJ \& Ny T 2004 Tissue-type plasminogen activator and its inhibitor plasminogen activator inhibitor type 1 are coordinately expressed during ovulation in the rhesus monkey. Endocrinology 145 1767-1775.

Lussier JG, Matton P \& Dufour JJ 1987 Growth rates of follicles in the ovary of the cow. Journal of Reproduction and Fertility $\mathbf{8 1}$ 301-307.

Lussier JG, Matton P, Guilbault LA, Grasso F, Mapletoft RJ \& Carruthers TD 1994 Ovarian follicular development and endocrine responses in follicular-fluid-treated and hemi-ovariectomized heifers. Journal of Reproduction and Fertility 102 95-105.

Macchione E, Epifano O, Stefanini M, Belin D \& Canipari R 2000 Urokinase redistribution from the secreted to the cell-bound fraction in granulosa cells of rat preovulatory follicles. Biology of Reproduction 62 895-903.

Murdoch WJ 1998 Regulation of collagenolysis and cell death by plasmin within the formative stigma of preovulatory ovine follicles. Journal of Reproduction and Fertility 113 331-336.

Ndiaye K, Fayad T, Silversides DW, Sirois J \& Lussier JG 2005 Identification of down-regulated messenger RNAs in bovine granulosa cells of dominant follicles following stimulation with human chorionic gonadotropin. Biology of Reproduction 73 324-333.

Ny T, Wahlberg P \& Brandstrom IJ 2002 Matrix remodeling in the ovary: regulation and functional role of the plasminogen activator and matrix metalloproteinase systems. Molecular and Cellular Endocrinology 187 29-38.

Ouellette Y, Price CA \& Carriere PD 2005 Follicular fluid concentration of transforming growth factor- $\beta 1$ is negatively correlated with estradiol and follicle size at the early stage of development of the first-wave cohort of bovine ovarian follicles. Domestic Animal Endocrinology 29 623-633.

Price CA, Carrière PD, Bhatia B \& Groome NP 1995 Comparison of hormonal and histological changes during follicular growth, as measured by ultrasonography, in cattle. Journal of Reproduction and Fertility 103 63-68.

Richards JS, Russell DL, Ochsner S \& Espey LL 2002 Ovulation: new dimensions and new regulators of the inflammatory-like response. Annual Reviews of Physiology 64 69-92.

Robert C, McGraw S, Massicotte L, Pravetoni M, Gandolfi F \& Sirard MA 2002 Quantification of housekeeping transcript levels during the development of bovine preimplantation embryos. Biology of Reproduction 67 1465-1472.

Rodgers RJ, Irving-Rodgers HF \& Russell DL 2003 Extracellular matrix of the developing ovarian follicle. Reproduction 126 415-424.

Rossignol P, Ho-Tin-Noe B, Vranckx R, Bouton MC, Meilhac O, Lijnen HR, Guillin MC, Michel JB \& Angles-Cano E 2004 Protease nexin-1 inhibits plasminogen activation-induced apoptosis of adherent cells. Journal of Biological Chemistry 279 $10346-10356$.

Shen X, Minoura H, Yoshida T \& Toyoda N 1997 Changes in ovarian expression of tissue-type plasminogen activator and plasminogen activator inhibitor type-1 messenger ribonucleic acids during ovulation in rat. Endocrine Journal 44 341-348.

Silverman GA, Bird PI, Carrell RW, Church FC, Coughlin PB, Gettins PG, Irving JA, Lomas DA, Luke CJ , Moyer RW et al. 2001 The serpins are an expanding superfamily of structurally similar but functionally diverse proteins. Evolution, mechanism of inhibition, novel functions, and a revised nomenclature. Journal of Biological Chemistry $27633293-33296$.

Sirois J 1994 Induction of prostaglandin endoperoxide synthase-2 by human chorionic gonadotropin in bovine preovulatory follicles in vivo. Endocrinology $135841-848$.

Tsai SJ, Wiltbank MC \& Bodensteiner KJ 1996 Distinct mechanisms regulate induction of messenger ribonucleic acid for prostaglandin (PG) G/H synthase-2, PGE (EP3) receptor, and PGF2 alpha receptor in bovine preovulatory follicles. Endocrinology 137 $3348-3355$

Received 16 June 2005

First decision 2 August 2005

Revised manuscript received 9 August 2005

Accepted 12 September 2005 